\title{
Perusahaan Keluarga, Koneksi Politik \& Kinerja Perusahaan
}

\author{
Lidya Utamaningsi \\ Fakultas Ekonomi, Pascasarjana Akuntansi, Universitas Andalas \\ Correspondence email: lidya.utamaningsi@gmail.com
}

\begin{abstract}
Abstrak. Perusahaan keluarga mendominasi sektor swasta di Indonesia dan berkontribusi 13.4\% dari GDP negara. Perusahaan keluarga memiliki horizon investasi yang lebih Panjang daripada pemegang saham karena pendiri ingin terus mewariskan perusahaan kepada generasi-generasi berikutnya. Untuk mencapai tujuan tersebut perusahaan akan berupaya mengatasi kendala eksternal perusahaan. Caranya adalah melalui koneksi politik. Dengan koneksi politik perusahaan akan mendapatkan berbagai keuntungan sehingga pada akhirnya akan berkontribusi pada kinerja perusahaan. Tulisan ini merupakan telaah literatur mengenai perusahaan keluarga dan koneksi politik. Berdasarkan hasil telaah, peneliti menyimpulkan bahwa perusahaan keluarga memiliki kinerja yang lebih baik daripada perusahaan non keluarga. Perusahaan terkoneksi politik memiliki kinerja yang lebih baik daripada perusahaan yang tidak terkoneksi politik selama masa pemerintahan politikus terkait. Perusahaan keluarga terkoneksi politik memiliki kinerja yang lebih baik daripada perusahaan keluarga yang tidak terkoneksi politik.
\end{abstract}

Kata kunci: Kinerja perusahaan; koneksi politik; perusahaan keluarga

Abstract. Family businesses dominate the private sector in Indonesia and contribute 13.4\% of the country's GDP. The family company has a longer investment horizon than the shareholders because the founder wants to continue bequeath the company to subsequent generations. To achieve these objectives the company will try to overcome the company's external constraints. The trick is through political connections. With a political connection the company will get various benefits so that it will ultimately contribute to the company's performance. This paper is a literature review of family businesses and political connections. Based on the results of the study, the researchers concluded that the family company had better performance than the non-family company. Politically connected companies have better performance than companies that are not politically connected during the reign of politicians concerned. Politically connected family companies have better performance than politically connected family companies.

Keywords: Company performance; political connections; family company

\section{PENDAHULUAN}

Grup bisnis milik keluarga atau perusahaan keluarga mendominasi sektor swasta di Indonesia (Patrick, 2002). Pergerakan finansial bisnis grup perusahaan ini memiliki peranan dalam membentuk kondisi ekonomi negara yakni sebesar $12.7 \%$ - 13.4\% dari GDP Indonesia (Lukviarman, 2004). Besarnya peranan grup keluarga ini terhadap kondisi ekonomi negara menjadikan topik perusahaan keluarga selalu menarik untuk ditelaah.

Perusahaan keluarga memiliki horizon investasi yang lebih panjang daripada pemegang saham. Keluarga pemilik menghargai kepemilikannya sebagai aset yang akan diteruskan pada generasi berikutnya (Cheng, 2014). Agar perusahaan keluarga dapat berkembang dan terus diwariskan kepada generasi-generasi penerus, perusahaan perlu mengatasi semua kendala internal dan eksternal. Kendala internal berasal dari dalam perusahaan dan dapat dikendalikan oleh perusahaan. Kendala eksternal berasal dari luar perusahaan dan tidak dapat dikendalikan perusahaan, seperti tindakan politis pemerintah berupa regulasi, subsidi, pajak dan lainnya (Watts \& Zimmerman, 1990).

Cara untuk meminimalisir kendala eksternal tersebut adalah dengan membuat koneksi politik. Secara sederhana koneksi politik merupakan hubungan antara politisi atau pejabat pemerintah dengan bisnis (perusahaan) untuk mencapai tujuan tertentu. Koneksi politik dapat menguntungkan perusahaan dalam beberapa sisi seperti: memperoleh kontrak dan subsidi dari Pemerintah (Baysinger, 1984), perlakuan pajak yang lebih baik (Faccio, 2006), akses yang lebih mudah untuk memperoleh pendanaan (Khwaja \& Mian, 2005), pengawasan yang kurang ketat (Stigler, 1971) dan bahkan harga IPO yang lebih tinggi (Francis et al, 2009). Manfaat tersebut pada akhirnya dapat membuat kinerja yang lebih baik daripada perusahaan lain yang tidak memiliki koneksi politik (Hillman, 2005) dalam Muttakin dkk., (2015).

Penelitian terdahulu menemukan hasil yang tidak sejalan mengenai hubungan perusahaan keluarga, koneksi politik dan kinerja perusahaan. Terdapat penelitian yang menyatakan bahwa perusahaan keluarga dan terkoneksi politik berhubungan positif dengan kinerj perusahaan. dan terdapat pula sekelompok penelitian yang menemukan sebaliknya. Hal ini menarik untuk ditelaah lebih lanjut karena beragamnya hasil yang ada.

Berdasarkan kondisi tersebut maka tulisan ini ditujukan untuk menjelaskan tentang :(a) apakah perusahaan keluarga memiliki kinerja yang lebih baik daripada perusahaan non-keluarga (b) apakah perusahaan terkoneksi politik memiliki kinerja yang 
lebih baik daripada perusahaan yang tidak terkoneksi politik (c) apakah perusahaan keluarga yang terkoneksi politik memiliki kinerja yang lebih baik daripada perusahaan keluarga yang tidak terkoneksi politik.

\section{METODE}

Tulisan ini merupakan kajian literatur dengan menelaah artikel dari tahun yang berkaitan dengan topik perusahaan keluarga, koneksi politik dan kinerja perusahaan secara umum dan dalam konteks kondisi di Indonesia.

\section{HASIL DAN PEMBAHASAN Agency Theory}

Agency theory mendeskripsikan hubungan antara pemegang saham sebagai prinsipal dan manajemen sebagai agen. Manajemen merupakan pihak yang dikontrak oleh pemegang saham untuk bekerja demi kepentingan pemegang saham. Karena mereka dipilih, maka pihak manajemen harus mempertanggungjawabkan semua pekerjaannya kepada pemegang saham.

Konflik kepentingan antara berbagai pihak tersebut disebabkan karena perbedaan tujuan dari masing-masing pihak, sesuai dengan posisi dan kepentingannya masing-masing. Namun demikian, mengidentifikasi pihak mana yang memiliki konflik paling dominan dengan pemilik perusahaan adalah bagian terpenting dalam menentukan karakteristik dari masalah keagenan. Hal ini dapat dilakukan dengan melihat struktur kepemilikan perusahaan sebagai basis dalam menentukan distribusi kekuasaan antara berbagai pihak di dalam perusahaan. Jensen \& Warner (1988) menyatakan bahwa hal ini disebabkan karena pola konsentrasi kepemilikan dan komposisinya akan menentukan pihak mana yang memiliki kekuasaan dominan di dalam perusahaan (Lukviarman, 2016 hal.54).

Keberadaaan pemegang saham dengan jumlah mayoritas (holder of block shareholders) dinyatakan mampu memberikan manfaat kepada korporasi dan pada akhirnya manfaat tersebut juga akan diperoleh semua pemegang saham. Proponen penganut pandangan ini (misalnya Brickley dan Dark, 1987) memberikan argumentasi bahwa sebuah korporasi yang dimiliki dan dikendalikan oleh pemegang saham mayoritas memiliki insentif yang kuat untuk meyakinkan bahwa 'the capital is deployed sparingly and used efficiently and that indirect production costs are tightly managed' (p.404). Alasannya adalah efek insentif dari pola kepemilikan tersebut akan mengurangi kebutuhan pengawasan dan supervisi dari pihak lainnya diluar perusahaan, sehingga akan mengurangi monitoring costs sebagai salah satu komponen biaya keagenan. Pola demikian dianggap dapat memitigasi masalah free riding, sehingga memungkinkan pengendalian untuk dilaksanakan lebih efektif (Lukviarman, 2016 hal.56).
Keuntungan lainnya melalui keberadaan pemegang saham pengendali akan diperoleh bagi perusahaan yang terafiliasi dengan kelompok bisnis (business groups affiliation). Manfaat ini dihasilkan melalui pemanfaatan transfer dana secara internal (financial tunneling) antara perusahaan didalam grup yang sama guna mangatasi ketidakefisienan pasar modal dalam menyediakan sumber pembiayaan sebagaimana ditermukan di berbagai negara berkembang. (Lukviarman, 2016 hal.57).

Jensen dan werner (1988) berpendapat bahwa struktur kepemilikan suatu korporasi akan menentukan karakteristik problem keagenan (agency problem) sehingga akan memetakan pembagian antara kekuasaan dan pengawasan dalam suatu entitas korporasi. Terdapat insentif bagi pemilik perusahaan yang menguasai jumlah saham yang besar untuk memonitor secara intens investasi yang dilakukan, dengan asumsi bahwa tingkat pengendalian yang dilakukan akan meningkat sesuai besaran porsi saham yang dimiliki (Lukviarman, 2016 hal.174).

Penelitian yang dilakukan oleh Lukviarman (2004) menemukan bahwa kepemilikan mayoritas perusahaan terbuka di Indonesia terkonsentrasi pada sekelompok individual, keluarga atau kepemilikan atau perusahaan lainnya. Kondisi ini terutama ditemukan pada perusahaan nasional dimana kepemilikan keluarga yang mengendalikan perusahaan terbuka, pada hakikatnya menguasai hampir keseluruhan pengendalian atas perusahaan oleh kelompok bisnis yang dimiliki oleh keluarga mereka. Karakteristik tersebut mengindikasikan bahwa terdapat kecenderungan rendahnya pemisahan antara kepemilikan dan pengendalian atas korporasi, karena pengendalian utama tetap berada pada pemilik awal yang memiliki saham dalam porsi besar sehingga secara teknis memiliki pengendalian penuh atas perusahaan.

\section{Perusahaan Keluarga}

Struktur dan praktik kelompok bisnis berbasis keluarga didasarkan kepada 2 hal utama yakni melindungi kepentingan keluarga dan tidak percaya kepada pihak lain yang berasal dari luar keluarga. Dengan diadopsinya struktur tersebut memiliki makna bahwa tidak terdapat peluang bagi individu dari luar keluarga untuk dapat diterima dalam kelompok bisnis keluarga, terutama bagi pihak yang dianggap dapat mengancam kepentingan keluarga. Struktur perusahaan juga ditujukan sebagai wadah untuk melindungi kelompok bisnis keluarga dari berbagai potensi ancaman maupun tantangan yang akan membahayakan kepentingan keluarga (Lukviarman, 2004).

Lukviarman (2004) menyatakan bahwa melalui penelusuran terhadap jalur pengembangan perusahaan di Indonesia, mulai dari perusahaan yang bersifat tertutup hingga berkembang menjadi pembentukan kelompok bisnis, peran dari kepemilikan keluarga tetap signifikan. 
Peran ini menjadi semakin kuat terutama melalui keterlibatan anggota keluarga pemilik didalam kepengurusan perseoran, serta rantai kepemilikan (chain of ownership) perusahaan melalui kepemilikan silang dengan perusahaan afiliasi.

Berdasarkan hasil telaah literatur, peneliti menemukan definisi perusahaan keluarga, yang dirinci pada tabel 1.

Tabel 1. Definisi Perusahaan Keluarga

\begin{tabular}{|c|c|c|}
\hline No & Peneliti & Definisi \\
\hline \multirow[t]{7}{*}{1} & Cheng (2014) & Keluarga pendiri dan keturunan \\
\hline & Golden \& Kohlbeck & keluarga \\
\hline & (2016) & memegang jabatan puncak \\
\hline & & perusahaan atau selalu sebagai \\
\hline & & \\
\hline & & (Anderson \& Reeb, 2003; \\
\hline & & $\begin{array}{l}\text { Villalonga \& Amit, 2006; Ali } \\
\text { dkk. 2007). }\end{array}$ \\
\hline \multirow[t]{8}{*}{2} & Waterhouse & Mayoritas 'suara' berada di \\
\hline & Coopers - Indonesia & tangan pendiri atau orang yang \\
\hline & (2014) & $\begin{array}{l}\text { mengakuisisi perusahaan (atau } \\
\text { pasangan, orang tua, anak atau } \\
\text { ahli waris) }\end{array}$ \\
\hline & & $\begin{array}{l}\text { Minimal terdapat } 1 \text { perwakilan } \\
\text { keluarga yang terlibat dalam } \\
\text { manajemen perusahaan }\end{array}$ \\
\hline & & $\begin{array}{l}\text { Untuk perusahaan publik (Tbk), } \\
\text { pendiri atau orang yang } \\
\text { mengakuisisi perusahaan (atau } \\
\text { keluarganya) memiliki } 25 \% \text { hak }\end{array}$ \\
\hline & & atas perusahaan melalui \\
\hline & & penanaman modal dan ada \\
\hline & & $\begin{array}{l}\text { setidaknya satu orang anggota } \\
\text { keluarga dalam manajemen } \\
\text { (board). }\end{array}$ \\
\hline
\end{tabular}

Berdasarkan UU No. 40 Tahun 2007 tentang Peseroan Terbatas, dinyatakan bahwa dewan komisaris dan dewan direksi dipilih dan diberhentikan melalui RUPS. Kondisi ini berbeda dengan kondisi two-tiers board regime lainnya, untuk kasus Indonesia baik dewan komisaris maupun dewan direksi berada dibawah kendali pemegang saham. Direksi sebagaimana Board of Management bertanggung jawab dan memiliki akuntabilitas kepada pemegang saham. Direksi tidak bertanggung jawab dan akuntabel kepada dewan komisaris sebagaimana ditemukan pada sistem dua tingkat lainnya seperti di negara Belanda. Memperhatikan tipikal dominannya perusahaan dengan pemilik pengendali pada perusahaan di Indonesia, maka pemegang saham mayoritas memiliki hubungan langsung baik dengan dewan komisaris dan atau dewan direksi. Melalui keterlibatan anggota pemilik dalam pengurus perseroan tersebut mereka dapat memfasillitasi pemilik pengendali dalam menjaga pengaruh mereka dalam keputusan operasional perusahaan (Lukviarman, 2016 hal.191).

Price Waterhouse Cooper (2014) menyatakan bahwa perusahaan keluarga memiliki 2 keunggulan.
Pertama, perusahaan memiliki sifat kewirausahaan yang lebih unggul. Kedua. keputusan dapat diambil dengan lebih efisien.

Perusahaan keluarga memiliki berbagai keunikan, yaitu (1) memiliki sifat kewirausahaan yang lebih unggul (2) keputusan dapat diambil dengan lebih efisien (PWC, 2014) (3) keluarga pemilik memiliki horizon investasi yang lebih panjang daripada pemegang saham. Keluarga pemilik menghargai kepemilikannya sebagai aset yang akan diteruskan pada generasi berikutnya (4) anggota keluarga secara aktif terlibat dalam manajemen perusahaan, baik dalam dewan direksi ataupun komisaris (Cheng, 2014).

Karakteristik unik tersebut memberikan gambaran bahwa perusahaan keluarga cenderung untuk memiliki performa yang lebih baik daripada perusahaan non keluarga. Namun demikian, kepemilikan secara terkonsentrasi mendapat kritikan dari Shleifer dan Vishny (1997); La Porta, Lopez-de Silanes dan Shleifer (1999) dan Bebchuk, Kraakman \& Triantis (2000) karena merugikan kepentingan stakeholder lainnya. Kondisi ini menjadi semakin diperburuk ketika pemilik pengendali juga terlibat sebagai bagian dari direksi dan/atau komisaris. Jika ini terjadi maka tingkatan masalah keagenan tidak lagi seperti yang ditemukan dalam pola tradisional antara manajer dengan pemilik sebagaimana ditemukan dalam perusahaan dengan kepemilikan yang menyebar (widely dispersed ownership).

Ketika kepemilikan terkonsentrasi pada keluarga pemilik mayoritas sehingga memiliki otoritas pengendalian yang besar terhadap perusahaan, maka masalah keagenan telah beralih dari pola tradisional menjadi masalah keagenan antara pemegang saham pengendali (yang juga terlibat dalam kepengurusan perseroan) dengan pemegang saham minoritas. Pihak pemilik mayoritas dapat mempengaruhi keputusan korporasi yang akan menguntungkan kelompok mereka, sementara biaya keagenan juga ikut ditanggung oleh pemilik minoritas (Lukviarman, 2016 hal. 56).

Disamping hal diatas, keberhasilan sebuah perusahaan tidak terlepas dari pengaruh lingkungan dimana perusahaan tersebut didirikan. Salah satu faktor lingkungan yang berpengaruh terhadap keberhasilan perusahaan ialah politik (Wulandari \& Raharja, 2013).

\section{Koneksi Politik}

Definisi politik menurut Budiardjo (1997) adalah berbagai kegiatan dalam suatu sistim politik (atau negara) yang menyangkut proses menentukan tujuan dari sistim tersebut dan melaksanakan tujuan tersebut. Salah satu bagian dari politik ialah partai politik (Wulandari \& Raharja, 2013).

Berlakunya UU No. 2 tahun 2011 Pasal 34 dan 35 yang mengatur sumber keuangan dan batas maksimum sumbangan untuk partai politik memberikan gambaran bahwa salah satu sumber keuangan partai politik adalah 
sumbangan dari perusahaan dan/atau badan usaha. Etika balas budi yang masih kental di Indonesia memberikan pandangan bahwa sumbangan yang diberikan perusahaan pada partai politik tidak secara gratis. Perusahaan yang berorientasi mencari keuntungan mengharapkan adanya timbal balik atau manfaat yang diperoleh dari sumbangan tersebut. Dari hubungan antara perusahaan dan partai politik kemudian muncul istilah perusahaan terkoneksi politik (Wulandari \& Raharja, 2013).

Perusahaan yang terkoneksi politik merupakan hal yang lumrah di berbagai perusahaan dunia, terutama bagi perusahaan yang kepemilikannya terkonsentrasi. Indonesia merupakan negara dengan perusahaan yang memiliki koneksi politik terbanyak (Faccio, 2006).

Berdasarkan telaahan peneliti, berikut definisi koneksi politik:

Tabel 2. Definisi Koneksi Politik

\begin{tabular}{ccl}
\hline No & Peneliti & \multicolumn{2}{c}{ Definisi } \\
\hline 1 & Faccio (2006) & Apabila salah satu petinggi \\
& & perusahaan dan atau pemegang \\
& & saham pernah menjabat atau \\
& merupakan anggota parlemen, \\
& & menteri dan keluarga menteri, \\
& memiliki hubungan dekat dengan \\
& politisi dan/atau memiliki \\
& hubungan dekat dengan politisi \\
& dari negara lain. \\
& & Apabila perusahaan memberikan \\
& Fontribusi keuangan kepada partai \\
& Ferguson \& Voth \\
& (2008) &
\end{tabular}

Perusahaan yang memiliki koneksi politik di Indonesia memperoleh dua keuntungan. Pertama, koneksi politik dapat memberikan kemudahan dalam memperoleh pendanaan. Husnan (2001) menemukan bahwa perusahaan terkoneksi politik dapat dengan mudah memperoleh pendanaan melalui 'memo' dari politisi. Kedua, perusahaan yang memiliki koneksi politik memperoleh keringanan pajak dan kekuatan pasar yang lebih tinggi (Faccio, 2002 dalam Wijantini, 2017).

Dalam literatur ekonomi dan keuangan, koneksi politik juga dikenal sebagai perilaku perburuan rente yang menggambarkan kepentingan pribadi yang dimiliki oleh politikus dan pengusaha. Dengan kata lain, politikus memberikan akses kepada pengusaha terkait dengan kekuasaan yang dimilikinya dengan mengharapkan imbalan. Para ekonomis bahkan menggunakan istilah korupsi daripada transaksi illegal untuk menggambarkan koneksi politik karena tindakan ini sah (legal) di banyak negara (Wijantini, 2007).

\section{Penelitian Terdahulu \\ Kinerja Perusahaan Keluarga}

Konsentrasi kepemilikan cenderung banyak terjadi pada negara dengan lingkungan regulasi yang lemah dimana risiko litigasi bersifat rendah (Monem, 2013). Perlindungan investor yang lemah (La Porta et al. 1998;
La Porta et al. 1999), penegakan sistem hukum yang lemah (La Porta et al. 1999), dan risiko apropriasi yang tinggi (La Porta et al. 1998; Lee et al. 2003) dalam Muttakin dkk (2015). Sehingga perusahaan keluarga cenderung lebih umum pada ekonomi berkembang, termasuk Indonesia.

Perusahaan keluarga berbeda dengan perusahaan non keluarga dalam berbagai aspek. Dalam bidang manajemen strategik, pandangan Resource Based View (RBV) memberikan kerangka teori yang menjelaskan bagaimana perusahaan keluarga dengan keunikannya mampu menciptakaan daya saing (competitive advantage) dan menghasilkan kinerja yang lebih baik dari perusahaan lainnya (Habbershon \& Williams, 1999). Karakteristik unik yang membentuk keunggulan bersaing bagi perusahaan keluarga adalah tempat kerja yang berorientasi keluarga dan tingginya loyalitas karyawan (Ward, 1988), rendahnya biaya SDM (Levering \& Moskowitz, 1993), rendahnya biaya transaksi (Aronoff \& Ward, 1995), reputasi yang lebih dipercaya (Tagiuri \& Davis, 1996; Ward \& Aronoff, 1991) serta rendahnya biaya monitor dan kontrol (Daily \& Dollinger, 1992) (dalam Muttakin dkk, 2015).

Hubungan keluarga akan memberikan motivasi yang tinggi, loyalitas yang tinggi dan rasa percaya yang tinggi (Tagiuri \& Davis, 1996). Perusahaan keluarga memiliki kemampuan untuk membuat anggota keluarga mengeluarkan kemampuan terbaiknya (Moscetello, 1990). Bahkan perusahaan keluarga cenderung memiliki horizon investasi yang lebih panjang (Stein, 1988) karena perusahaan keluarga fokus untuk meneruskan usaha kepada generasi berikutnya sehingga akan menghasilkan investasi yang sangat efisien. Dapat disimpulkan bahwa karakteristik unik dari perusahaan keluarga dapat mendorong terciptanya efisiensi biaya operasional, tingkat produktivitas karyawan yang tinggi serta investasi yang lebih efisien sehingga pada akhirnya menghasilkan kinerja yang lebih baik bila dibandingkan dengan perusahaan non keluarga (Muttakin dkk, 2015).

Penjelasan diatas memberikan gambaran bahwa pada kondisi ekonomi berkembang, perusahaan keluarga memiliki kinerja yang lebih baik daripada perusahaan non keluarga. Berikut hasil telaah literatur terkait perusahaan keluarga.

Tabel 3. Hasil penelitian perusahaan keluarga

\begin{tabular}{|c|c|c|}
\hline No & Peneliti & Temuan \\
\hline 1 & $\begin{array}{l}\text { Muttakin, } \\
\text { dkk (2015) }\end{array}$ & $\begin{array}{l}\text { 1. Perusahaan keluarga memiliki kinerja } \\
\text { yang lebih baik daripada perusahaan } \\
\text { non keluarga } \\
\text { 2. Perusahaan keluarga yang terkoneksi } \\
\text { politik lebih baik daripada perusahaan } \\
\text { keluarga yang tidak terkoneksi politik }\end{array}$ \\
\hline 2 & $\begin{array}{l}\text { Lukviarman } \\
(2004)\end{array}$ & $\begin{array}{l}\text { Tidak terdapat dampak positif } \\
\text { kepemilikan terkonsentrasi terhadap } \\
\text { kinerja perusahaan pada perusahaan } \\
\text { terbuka di Indonesia. }\end{array}$ \\
\hline
\end{tabular}


Indonesia dan Bangladesh merupakan dua negara dengan ekonomi berkembang dan dengan tingkat korupsi yang tinggi (Indonesia peringkat 37, Bangladesh peringkat 28 cf. Corruption Perception Index 2018) serta sama-sama memiliki porsi perusahaan keluarga yang mendominasi bisnis di negara masing-masing sehingga diperkirakan akan memberikan dampak sifat perusahaan keluarga yang sama terhadap perusahaan. Namun demikian, berdasarkan tabel 3 diatas terlihat bahwa terdapat hasil yang berbeda sehingga perlu dilakukan kembali penelitian dengan pendekatan yang lebih komprehensif untuk melihat apakah perusahaan keluarga lebih baik daripada perusahaan non keluarga pada negara ekonomi berkembang.

\section{Kinerja Perusahaan Keluarga Yang Terkoneksi Politik}

Koneksi politik dapat menguntungkan perusahaan dalam beberapa sisi seperti: memperoleh kontrak dan subsidi dari Pemerintah (Baysinger, 1984), perlakuan pajak yang lebih baik (Faccio, 2006), akses yang lebih mudah untuk memperoleh pendanaan (Khwaja \& Mian, 2005a), pengawasan yang kurang ketat (Stigler, 1971) dan bahkan harga IPO yang lebih tinggi (Francis et al, 2009). Manfaat tersebut pada akhirnya dapat membuat kinerja yang lebih baik daripada perusahaan lain yang tidak memiliki koneksi politik (Hillman, 2005) dalam Muttakin dkk., (2015).

Perbedaan dalam hal kinerja antara perusahaan yang memiliki koneksi politik dengan yang tidak menjadi semakin jelas ketika koneksi politik semakin kuat dan ketika perusahaan yang memiliki koneksi politik tersebut beroperasi pada negara-ngeara dengan level korupsi yang tinggi (Faccio, 2006) seperti Indonesia yang merupakan negara korupsi nomor 37 di dunia (Corruption Perception Index, 2017). Sehingga di negara seperti Indonesia, memelihara koneksi politik dapat memberikan sebuah keunggulan bersaing yang akan menghasilkan kinerja perusahaan yang lebih baik.

Secara khusus, koneksi politik dapat membantu perusahaan mengeksploitasi kelemahan dari lingkungan institusional dan memperoleh keuntungan ekonomis dari sisi regulasi yang menguntungkan (favorable), akses pendanaan yang lebih mudah, perlindungan pasar, perlakuan pajak yang berbeda. Dapat disimpulkan dalam lingkungan peraturan yang lemah, perusahaan keluarga yang memiliki koneksi politik berada pada posisi terbaik untuk mengambil keuntungan dari lingkungan institusional karena terdapat insentif yang kuat dan sama antara manager dan pemegang saham perusahaan. Sehingga perusahaan keluarga yang memiliki koneksi politik akan cenderung memiliki kinerja yang lebih baik daripada perusahaan keluarga yang tidak memiliki koneksi politik (Muttakin, 2015).

Dari hasil telaah peneliti, berikut hasil penelitian terdahulu mengenai koneksi politik.
Tabel 4. Hasil penelitian koneksi politik

\begin{tabular}{|c|c|c|}
\hline No & Peneliti & Temuan \\
\hline \multirow[t]{3}{*}{1} & Leuz \& & 1. Perusahaan dengan koneksi politik \\
\hline & Gee (2006) & $\begin{array}{l}\text { kurang cenderung untuk terdaftar di } \\
\text { bursa perdagangan } \\
\text { internasional. }\end{array}$ \\
\hline & & $\begin{array}{l}\text { 2. Perusahaan dengan koneksi politik } \\
\text { cenderung memiliki kesulitan untuk } \\
\text { membangun kembali hubungan } \\
\text { politik dengan rezim Pemerintahan } \\
\text { baru dan kinerja perusahaan } \\
\text { cenderung menurun ketika terjadi } \\
\text { pergantian rezim Pemerintahan. }\end{array}$ \\
\hline
\end{tabular}

2 Wulandari Perusahaan yang memiliki koneksi politik (2012) memiliki kinerja lebih rendah dalam dibandingkan dengan perusahaan yang Sotartagam tidak terkoneksi politik.

(2015)

3 Quonch-

Anh Do,

Yen-Teik

Lee \&

Bang Dang

Nguyen

(2012)

dalam

Sotartagam

(2015)

4 Wulandari

\& Raharja

(2013)

1. Koneksi ke Gubernur terpilih meningkatkan nilai perusahaan $1,36 \%$ sekitar Pemilu.

2. Perusahaan yang terhubung ke pemenang Pemilu menerima proyek Pengadaan lebih banyak, berinvestasi lebih banyak dan menikmati kinerja saham jangka panjang yang lebih baik.

1. Koneksi politik berpengaruh negatif terhadap kinerja perusahaan. Perusahaan yang terkoneksi politik memiliki ROA lebih rendah daripada perusahaan yang tidak terkoneksi politik

2. Kepemilikan saham publik tidak berpengaruh positif terhadap kinerja perusahaan. Hal ini disebabkan karena rendahnya tingkat kepemilikan saham oleh publik di Indonesia dan besarnya kendali oleh pemegang saham mayoritas atau pengendali membuat pemegang saham publik tidak bisa banyak mengambil kebijakan.

5 Goldman, Analisis respon terhadap kemenangan Rochol \& partai Republik pada pemilihan Presiden So (2006) USA tahun 2000 menunjukkan bahwa dalam perusahaan yang terhubung dengan partai Sotartagam Republik mengalami peningkatan nilai (2015) saham sedangkan perusahaan yang terhubung dengan partai Demokrat mengalami penurunan nilai saham.

6 Saeed, Terdapat hubungan negatif antara koneksi Belghitar politik dan kinerja perusahaan di Pakistan.

\& Ephraim

Clark

(2015)

Fisman (2001) menemukan bahwa harga saham pada perusahaan yang terdaftar di Jakarta Stock Exchange (JSE) berkorelasi merespon negatif atas pengumuman berita negatif terkait kesehatan Suharto. Facio (2006) dalam penelitiannya yang mengamati 47 
negara menemukan bahwa harga pasar saham meningkat secara signifikan ketika pemimpin puncak perusahaan atau pemegang saham terbesar memasuki dunia politik tetapi tidak terjadi ketika politikus bergabung dalam perusahaan (Wijantini, 2007).

Facio et al (2006) menemukan bahwa perusahaan yang mengalami kesulitan keuangan dan memiliki koneksi politik cenderung untuk dijamin oleh Pemerintah (bailout) namun hal tersebut tidak terjadi pada perusahaan yang tidak memiliki koneksi politik (Wijantini, 2007).

Secara rata-rata manfaat dari memiliki koneksi politik melebihi biaya yang harus dikeluarkan. Contoh, Fisman (2001) mempelajari koneksi antara perusahaan dengan Presiden Suharto dan menemukan rumor kesehatan Suharto yang memburuk secara signifikan (dan negatif) mempengaruhi harga saham perusahaan. Penelitian yang dilakukan oleh Goldman, Rocholl and So (2009) memberikan bukti bahwa koneksi politik melalui anggota Dewan Direksi secara rata-rata meningkatkan nilai perusahaan di US (Faccio, 2006).

\section{SIMPULAN}

Berdasarkan pembahasan diatas dapat disimpulkan bahwa perusahaan keluarga mendominasi di negara berkembang dan perusahaan keluarga dengan segala keunikan yang dimilikinya cenderung untuk memiliki kinerja yang lebih baik daripada perusahaan non-keluarga. Dengan segala ketidakpastian dari sisi kondisi ekonomi dan politik di negara berkembang seperti di Indonesia, perusahaan (termasuk perusahaan keluarga) akan cenderung untuk membuat koneksi politik karena akan memberikan dampak positif bagi perusahaan.

Berdasarkan hasil telaah peneliti menarik tiga kesimpulan. Pertama, perusahaan keluarga memiliki kinerja yang lebih baik daripada perusahaan non keluarga. Kedua, perusahaan terkoneksi politik memiliki kinerja yang lebih baik daripada perusahaan yang tidak terkoneksi politik selama masa pemerintahan politikus terkait. Ketiga, perusahaan keluarga terkoneksi politik memiliki kinerja yang lebih baik daripada perusahaan keluarga yang tidak terkoneksi politik.

\section{DAFTAR PUSTAKA}

Carrera., Nieves, 2017, What Do We Know About Accounting in Family Firms?, Journal of Evolutionary Studies in Business (JESB), Vol. 2, No. 2, hal $97-159,2017$.

Cheng, Qiang., 2014, Family Firm Research - A Review, China Journal of Accounting Research (2014).

Coopers, Price Waterhouse, 2014, Survey Bisnis Keluarga Indonesia 2014, https://www.pwc.com/id/en/publications/assets/in donesia-report-family-business-survey-2014.pdf
Faccio, Mara, 2006, Differences Between Political Connected And Nonconnected Firms: A CrossCountry Analysis, Financial Management Journal, hal. 905-927.

Ghosh., Aloke (Al), Charles T. Yang, 2015,

Assesing Financial Reporting Quality of Family Firms: The Auditors' Perspective, Journal of Accounting and Economics, Accepted Manuscript.

Habib., Ahsan, Abdul Haris Muhammadi, 2018, Political Connections and Audit Report Lag: Indonesian Evidence, International Journal of Accounting \& Information Management, RMIT University.

Khwaja, A. I., \& Mian, A. (2005). Do Lenders Favour Politically Connected Firms? Rent Provision in an Emerging Financial Market. The Quarterly Journal of Economics, 120(April), 371-1411. https://doi.org/10.1162/003355305775097524

Leuz,. Christian, Felix Oberholzer-Gee, 2006, Political Relationship, Global Financing and Corporate Transparency: Evidence From Indonesia, Journal of Financial Economics 81 (2006) hal. 411 - 439.

Lukviarman, Niki, 2016, Corporate Governance Menuju Penguatan Konseptual dan Implementasi di Indonesia, ISBN 978-602-1680-39-1, cetakan pertama, penerbit PT Era Adicitra Intermedia.

Lukviarman, Niki, 2004, Ownership Structure and Firm Performance : The Case of Indonesia, Doctoral Thesis.

Muttakin, Mohammad Badrul., Reza M. Monem, Arifur Khan, Nava Subramaniam, 2015, Family Firms, Firm Performance and Political Connections: Evidence From Bangladesh, Journal of Contemporary Accounting \& Economics (2015), Accepted Manuscript.

Saeed., Abubakr, Yacine Belghitar \& Ephraim Clark, 2015, Do Political Connections Affect Firm Performance? Evidence From a Developing Country, Journal of Emerging Markets Finance and Trade, halaman $1-12$.

Sotartagam., Rovelino Quayle. 2015, Analisis Pengaruh Political Connection Terhadap Nilai Perusahaan, Skripsi, Fakultas Ekonomika dan Bisnis, Universitas Diponegoro, Semarang.

Wijantini, 2007, A Test Of The Relationship Between Political Connection And Indirect Costs Of Financial Distress In Indonesia, Asian Academy Of Management Journal Of Accounting And Finance (AAMJAF), Vol.3. No. 2, 6-81, 2007.

Wulandari., Tri, Raharja, 2013, Analisis Pengaruh Political Connection dan Struktur Kepemilikan Terhadap Kinerja Perusahaan, Diponegoro Journal of Accounting, Volume 2, Nomor 1, Tahun 2013, Halaman $1-12$. 